\title{
Constructing Civil Society: An Islamic Cultural Perspective
}

\section{Mulyadhi Kartanegara1}

\author{
Miftachul Huda² \\ 1 Universiti Brunei Darussalam (UBD), Sultan Omar Ali Saifuddien Centre for Islamic Studies (SOASCIS), Jalan Tungku Link \\ BE 1410, Gadong, Bandar Seri Begawan, Brunei Darussalam. and State Islamic University (UIN) Syarif Hidayatullah Jakarta \\ Indonesia; mulyadhi.kartanegara@ubd.edu.bn \\ 2 Universiti Brunei Darussalam (UBD), Sultan Omar Ali Saifuddien Centre for Islamic Studies (SOASCIS), Jalan Tungku Link \\ BE 1410, Gadong, Bandar Seri Begawan, Brunei Darussalam
}

Doi:10.5901/mjss.2016.v7n1s1p126

\section{Abstract}

Since civil society has been widely recognised as the rich social network of recreational and political organizations, the study is almost viewed within political and social approach. There has been lack of scholarly attention to explore the historical and cultural approach into what kind of significant reflection should be taken into consideration for theoretical and practical aspect in our society. This study aims to critically explore civil society, which deals with the certain ideals based on the Islamic world. Critical literature review was conducted to investigate using a historical-cultural perspective to deal with civil society from lexicographical sense with the character of urban society. This study reveals that there is some core significant enlightenment for the formal structure of civil society. In particular, this study demonstrates that although the term of 'civil society' might have not yet been invented in the classical Islam and rather used in adab (civilised) and peradaban (civilisation), in practical level the core values criteria of civil society were already discussed, exercised and practiced by the proponents of Islamic culture long before the Western scholars invented the term 'civil society.' This is expected to contribute a better awareness and a more informed citizenry.

Keywords: Civil society, adab (etiquette), peradaban (civilised) inclusivism, humanism (egalitarianism), tolerance and democracy

\section{Introduction}

Civil society has been widely studied in the view of some western perspective where they are confirmed as evolving impactful and dynamic ways (Fukuyama, 2001; Kaldor, Anheier, \& Glasius, 2003; Newton, 2001). Being engaged with government, business and international organizations, civil society should provide the resilient dynamism that the world urgently needs. As a result, the power and influence of civil society are growing and should be harnessed to create trust and enable action across sectors (Hann \& Dunn, 1996; Hooghe \& Stolle, 2003; Scholte, 2002). Moreover, since civil society is usually viewed through common approach with the enlightenment and modernization characterized by 'individualism' and the emergence of democratic institutions (Inglehart \& Welzel, 2005), this challenging issue should be taken into consideration to the organizations and institutions that manifest citizens' interests and will. In particular, almost the study is seen within political and social approach, so that an attempt to elucidate its origin in the aspect of historical perspective has a chance to give a clear understanding on civil society.

In line with the attempt to elucidate civil society in the perspective of Islamic culture where there should be made a particular recognition and awareness on Islam not only as a religion with religious ritualism but also as a foundational way to guide the people in the right path involving in the social and political life. At this point of view, Islamic beliefs and traditions have been a major source to provide a fundamental basis on the political theory and legitimization of political power through in depth analysis into the position of the state in Muslim countries during a long history (Ayubi, 2003; Brown, 2013; Eickelman, Piscatori \& Piscatori, 2004; Tibi, 2001). With a highly influential sphere in the society, the role of religion and ulama (learned religious leaders) has a significant role in legitimizing political power within religious group. Moreover, Kamali (2006) underlined that the ulama played a major part in many social institutions, such as education, marriage, burials, the collection and redistribution of taxes, registration of property, and so forth. This indicates that the social relationship with cooperation makes the civil society with civilizational and peaceful spheres. In so far, an effort to construct how the civil society could be comprehended within will be able to contribute to the society through critical analysis in the view of theoretical approach towards the lexicographical basis. 
In this paper, core discussion on civil society will be investigated by putting forward the concrete forms of statements or actions and the proponents of Islamic culture. Reflecting the pattern of civil society in Islamic cultural perspective will also be discussed within historical approach. Moreover, in depth theoretical approach and critical review, this study is substantiated by some examples. In doing this, investigating the concept of civil society in the perspective of lexicographical sources could be conducted. To begin with, a brief discussion on 'Adab' in Islamic culture could be underlined to find the relevant into the characteristics of civil (madani) society. Furthermore, this will be continued indepth discussion on some relatively limited areas in the ideals of civil society. As a result, this refers to the proponents of Islamic culture theoretically and practically, mainly in the period of the glory of Islamic culture between the tenth and thirteenth centuries. In addition, some pattern and model at that time to what some great scholars have discussed in length on the civil society of earlier period of Islamic history will also be elucidated especially the period of our beloved Prophet and of his companions.

\section{Civil Society in General Discourse}

There are many discourses on civil society, in both peer-reviewed journals and books. Most of them already have been discussed on variety of approaches. Those are sociological perspective (Fukuyama, 2001), political view (Lipschutz, 1992; Newton, 2001), and social coherent perspective (Norton, 1993; Orjuela, 2003). In particular, civil society is not directly conditioned by the existence of 'sovereign' and 'free' individuals, but by groups or communities and their institutions enjoying a significant degree of autonomy from the state in many Islamic countries (Kamali, 2001). As a result, the level of autonomy to cooperate with these civic society groups has to do usually with social authority, legitimacy and socioeconomic institutions (Kamali, 2010). Above exposed discourse is based on the conceptual framework with specifying practice and particular example. Apart from that, we will discuss briefly on the lexicographical sense with the character of urban society. In this regard, dedication of citizens to the common welfare in the community and the cost of individual interests' civic virtue should be constituted on the character traits which have been a major concern of political philosophy. As a result, the term civility refers to behaviour between persons and groups that conforms to the civil society. Being a foundational principle of society, an attempt to comprehend its term in the level of personal and social living can be an important part for strengthening enlightenment for the community.

As a point of view to make more clearly viewed at the contemporary era, it is worthwhile to recognise civil society in its main word. The word 'madani has something to do with word 'madinah' (Ayubi, 2003). This indicates that the term of civil society has the distinct meaning to the city (urban) society as against village (rural) society. As a result, from several dictionaries we have consulted, we got impression that the term 'madinah' does not simply refer to a geographical locus, but instead, and this is more important for our discussion, which refers to the characteristics and certain traits essential to the society. At this point of view, it is important to note that the word urban which also means of city is closely related to the term urbane defined as polite and suave, smooth and polished in manner; courteous and affable (Hooghe \& Stolle, 2003).

In addition, it is necessary to recognise that civil society does not just refer to any people who live in a city. Rather, it refers to anyone who has characters or manners suitable to urban people (Kaldor, 2003). As a result, to understand this way it is possible that someone lives in a big city, but does not have characters or manner of urban people. Furthermore, it can be possibly pointed out that other lives in a village, but he has characters of urban civility or even civilization. The term civil in civil society is indeed related to word civilization (Bakar, 2010a). As widely known, it is related to the word 'civilized' which means having a civilization and in Arabic it is related to the word 'tamaddun' which also means civilization (Bakar, 2015; Kartanegara, 2007a). This considers being complex society characterized by urban development, social stratification, symbolic communication forms, and a perceived separation from and domination over the natural environment by cultural elite in the diverse society (Keane, 2003). At this point of view, there should be attempted on civil society to explore the ideal characteristics of an urban society as a fundamental notion into the physical-geographical urbanization.

\section{Reconstructing Adāb in the Islamic Culture}

With regard to main root of words about the civilisation, this word could be analysed within 'peradaban' (Indonesian) and 'tamaddun' (Malay) which has been transformed from Arabic word 'adab' (Bakar, 2015; Kartanegara, 2007a). In particular, ādāb basically has the meaning 'prolateness', 'good' and 'proper manners' (Wehr \& Cowan, 1979; Ryding, 2005). These proper manners which need to conduct (ādāb) have been developed and cultivated into those people who lived in great cities like Baghdad, Isfahan, Damascus and Cordoba etc., to distinguish their societies from those simple, 
rude and rustic societies such as found in the Bedouin societies (Kamali, 2006). In the history of Islamic civilization, we learn that the bigger a city was, the more refined people's civility became. For example, it can be viewed from insulting remarks received by accomplished philosophers of Khurasān, Abū al-Hasan al-'Āmirī (d. 983), from the people of Baghdad when he visited the city (Norton, 1993). He was ridiculed by them as being 'too rude' or 'unpolished' from the Baghdadi standards. On his return to Khurasân, he reported that the Irāqi were elegant on the surface but gross and hypocritical underneath and disdainful on non-Iraqis in general, and Khurasanis in particular. But later he said that 'the best thing for a man is be an Easterner (i.e. Khurasānī) in substance and an Iraqi in form; thereby he combines the elegance of the Iraqis with the solidity of the Khurasānīs' (Rowson, 1991).

In the context of building up civil society, it is why the 'ulamā' (Muslim scholars) had tried hard to develop the system of conducts (ādāb) in almost every aspect of human conducts, such as the proper way of eating, marriage, of putting on your cloth and of earning money etc. (al-Ghazali, n.d.; Netton, 2013). They also tried to compose the ethical manuals and books pertaining to various types of ādāb, such as proper way of seeking knowledge, of shelving the books, the art of writing, of criticizing, and also of uttering words and of conducting a debate. They did all of these in order to build, develop and refine the characters of urban society, so they would not be rustic and simple any more like rural societies. These attempts of urban citizens to build up the ideal characters of urban society have resulted in 'adab' which, in the Islamic context, means the patterns of cultivated living which grew up around the court and provincial centres, and was emulated yet more widely (Hodgson, 2009).

Moreover, these ādāb in Islamic culture do not confine its meaning into merely etiquette, but have been developed into more advanced and complex forms (Netton, 2013). As a result, adīb, which the subject of ādāb, was demanded to be a cosmopolite man, who possessed comprehensive information on various aspects of urban community lives. His knowledge should be widely enough to include not only Shari'ah as the principle of public order, but also various scientific disciplines such as biology, geography, philosophy and history (Kartanegara, 2003a). These disciplines are necessary to refine such moral values and characters to increase his aesthetic sensitivity. As a result, these disciplines are not only for their own sake, but also for the for the sake of adab. 'When an adīb studied biology,' Hodgson says, 'he was not so much interested in learning the structure of organism, as in finding out all the strange things that could be said of them (Hodgson, 2009). The aesthetic propriety of various ways of making literary references to the animals discussed was a major concern. In particular, these udabā' exposed through their various moral lessons from animal lives.

In addition, to take into consideration well in civil society through good lessons and practical wisdoms from the historical view, this can be applied within real-everyday life. With this regard, Shah Nāmah of Firdawsī, clearly indicates that hero kings were depicted as enormous figures embodying in themselves the whole social order in accordance with Iranian conception of absolute monarchy (Kamali, 2006). As a result, they really believed that a good monarch produced a blessed age, a weak and evil monarch meant catastrophe. As for geography, this particular science was needed by the adīb not only for administrative and commercial interests, but also for studying the Hadith transmitters who lived far away from each other (Ayubi, 2003). From adab perspective, however, geography could offer hidden treasures of wonders of the world or weird things that challenged the imagination and curiosity of the adīb to ponder upon, and were quite relevant to the development of adab itself (Brown, 2013). With this regard, the stories of the Arabian Nights were taken from the travels of the geographers, historians and travellers to the world.

Towards above, an adīb must be well capable on the Arabic literature, whose cores are poetry and rhymed prose. Like other disciplines, Arabic literature was seriously investigated to produce good and graceful words and expressions, for 'the well-spoken words and expressions will move the morally refined people' (Eickelman, Piscatori, \& Piscatori, 2004). With regard to being a particular view on the graceful and good society, the need to master the foundational standard within society, mainly Arabic, could create a good manner in terms of practice and remark or saying. Moreover, by mastering this Arabic, an adīb is expected to master the rich sources of vocabularies. In terms of producing good and enchanting words and expressions, poetry and rhymed prose were also often used to embellish and refine important documents, such as the state letters and orations by the viziers and sultans, so they come into stage full of enchantments and inspirations. Various types of poetry were created by the adībs, such as qașidah, rubā'i, mathnawī, ghazzāl, atc (Kartanegara, 2000a). Even khamriyyāt and mystical poems can be found abundant decorating the treasure of Islamic literature (Kartanegara, 1986). To refine the qualities, a number of literature critics such as Ibn al-Mu'tazz, Ibn Quthaybah, al-Mutanabbi etc. came to contribute their finest minds. Beside poetry, the adīb also had developed rhymed prose, including what we call now gnomological works (hikam) in the forms of compilations or collections of wise sayings, aphorism, or anecdotes of Greek or Muslim philosophers or sages (Kartanegara, \& Hizbullah, 2006). From such compilations we knew several works such as al-Hikmah al-Khālidah by Miskawayh, al-Kalim al-Rūhāniyyah by Ibn Hindū, and Mukhtār al-Ḥikam wa Maḥāsin al-Kalim by Mubashshir b. Fâtik (Kartanegara, 2009). Like poetry, these wise sayings (hikam) were often inserted in speeches or orations of government officers, to make their expressions more beautiful and 
their appearance more elegant.

In addition, to make the ideal type of civil society materialized, the udabā also produced a number of ethical works, whose purpose was to educate and refine people's characters (Kartanegara, \& Alkaf, 2007b). From this perspective, we appreciate the contributions of Muslim moral philosophers to this through their ethical works, such as Tahdhīb al-Akhlāq (the Refinement of Characters) by Miskawayh, al-Sa‘ādah wa al-Is‘ād by al-'Āmirī, Kitāb al-Akhlāq wa al-Siyar by Ibn Hazm and Akhlāq-i Nașīī (The Nasirean Ethics) by Nașîr al-Dīn Țūsī (Hodgson, 2012; Kartanegara, 2000a; Kartanegara, 2000b). In particular, these works discussed various virtues (faḍāili) and vices (radhïili) (Bakar, 2015) and moreover the cultivation of good characters and the avoidance of bad characters. Therefore, these ethical works were developed basically to refine characters and conducts in accordance with the ideals of civil societies to have ethical foundation (Huda, \& Kartanegara, 2015a). At this point of view, there could be determined that civil society in the meaning of social life has the distinct particular essence into being ethical society with educated and civilised personalities and qualities.

\section{The Ideals of Civil Society: Theories and Practices}

In terms of the ideals of civil society in the Islamic culture, we need to further elucidate on this particular subject. As a result, the discourse on civil society has been in general viewed from political perspective, in which the word civil is contrasted to military or ecclesiastic governments (Hann, \& Dunn, 1996; Inglehart \& Welzel, 2005; Kaldor, Anheier \& Glasius, 2003; Keane, 2003; Lipschutz, 1992). With this regard, civil society could appropriately confined to the cultural fields related to life attitudes or life orientations the urban society should possess, such as tolerance, inclusiveness, democracy of freedom of thought, egalitarianism, etc. Therefore, the term civil society here is taken in different meaning from the current one. In particular, in terms of the historical samples based on the ideals of civil society from the sayings or statements (theories) or actions (practices) among those proponents of the Islamic culture, they are 'ulamā', udabä' and Sufis or Muslim philosophers (Ayubi, 2003). It has similar with other big cities in the world right now, great cities in the Islamic world, especially Baghdad and Cordova, which were essentially pluralistic in nature, where populations with different ethnic, tribal, linguistic and religious backgrounds lived and blended together (Brown, 2013). As a result, this essence has created its own challenges to which in a particular urban people should answer by developing characters suitable to do with their cultural behavioural circumstance. Based on these characters, the urban society have developed with the ideals of civil societies, which include among the others, inclusivism, egalitarianism, tolerance and democracy.

\subsection{Inclusivism}

Inclusivism has actually been practiced by the udabā when they built their ādāb, for in addition to using the Qur'ān and hadith as their most authoritative sources, they also used other sources from various cultures (Bakti, 2005; Ryding, 2005). In poetry, for example, they appreciated and made use of the pre-Islamic heritage, even some of them used it as the standard for the quality and success of any particular poetry. Likewise, when they tried to take some moral lessons from animals, they used without hesitance, fables from foreign cultures, especially Indian, such as Kalīlah wa al-Dimnah by Indian sage, Bidpei. This work was translated into Arabic by Ibn Muqaffa' in the ninth century and became the ideal and standard work of its own for later generations (Fakhry, 2004). As for the moral examples of the heroes and wise kings, they used an epic of the Persian heroes and kings, such as Firdawsī's Shah Nāmah (Book of the Kings) (Leaman, 2013). They used for their purpose, a number of gnomological works (hikam) collected from the wise sayings of Persian, Arab, Greek and Indian sages. These sayings are comprehensively represented in Miskawayh's famous al-Hikmah alKhālidah (the Perennial Philosophy) (Miskawayh, 1959; Huxley, 2014) and other similar works like al-Kalim alRūhāniyyah (Hindū, 1900).

Like the udabâ' and Muslim scientists had also developed their inclusive attitude similar to them in their works. In mathematics, for example, Muslim mathematicians had learned a great deal from Indian mathematics (Kartanegara, 2005a; Kartanegara, 2005b). Al-Fazzārī with his complete name al-Khwarizmī in other version has already translated an Indian work, entitled Siddhanta al-Kubrā, into Arabic in the ninth century (Fakhry, 2004). This work later encouraged Muslim mathematicians to work more creatively, so many theories and discoveries were made by them. For example, alKhwarizmi was declared as the one who invented sifr (zero), a word which became 'cipher' and later 'zero when transferred to Europe (Bakar, 1999). In this regard, this could be considered to be a great mathematical revolution, incognito, since we cannot imagine mathematics without zero.

Likewise, the philosophers (falāsifah) have clearly demonstrated this inclusiveness (Leaman, 2013). They showed us their open-mindedness and felt confident to receive any foreign thoughts (Watt, 2008). There was no trace of any 
inferior complexity in them (Huxley, 2014). To those who insisted on the exclusive sources of the Qur'an and hadith for the truth, al-Kindī clearly said, the truth wherever it comes should be accepted, for there is nothing dearer to the seeker of truth that the truth itself (Kartanegara, 2000a). In particular, al-Kindī himself had learned almost all the branches of Greek philosophy and science with great confidence (Bakar, 1999; Kartanegara, 2003b). According to him, knowledge is accumulative in nature, and will never reache the height that we have now, if it were not due to the contributions our ancestors had made. Therefore, what we should do is to thank them by studying carefully their statements and doctrines. Once we understand them correctly, we might revise their theories and present them in our own language (Bakar, 1999; Kartanegara, 2002; Kartanegara, 2007a).

Furthermore, the similar attitude was also taken by another philosopher who lived after al-Kindī by the name of Abū al-Ḥasan al-'Āmirī (d. 893). In his work, Kitāb al-'Amad 'alā al-'Abad, he states that Greek philosophy and science cannot be viewed as completely foreign from Islamic prophetic tradition (Nasr, 2010). In particular, a number of great Greek philosophers like Hermes, Empedocles, and Pythagoras were very closely related to the prophetic tradition. According to al-'Āmirī, Hermes, very well respected by Greek philosophers including Aristotle, was not but Prophet Idris pbh, the third prophet after Adam and Shith (Leaman, 2013). Empedocles was being understood one of Luqmān al-Hakaīm's disciples, who used to keep company with Luqmān, and learn from his wisdom, Greeks attributed wisdom to Empedocles because of his former association with Luqmān. Moreover, he was the first Greek to be called a sage (Fakhry, 2004). Luqmān alHakīm lived in Syria and a contemporary of Prophet David pbh (Watt, 2008). As for Pythagoras, in Egypt he kept company with companions of Solomon (prophet Sulaymān) son of David, after they moved there from the Land of Syria (Huff, 2003). Having had learned geometry from the Egyptians, he then learned the physical and divine/metaphysical (ilāhiyyah) sciences from the companions of Solomon (așhāb Sulaymān). Later he transferred these three sciences to the land of Greece. Socrates was said by al-'Āmirī to derive his wisdom from Pythagoras, but he limited to the divine sciences, to the exclusion of the other kinds. The companions of Solomon came to Egypt after being expelled by Babylonian king from their country and well received by the king astronomer Ptolemy (Hodgson, 2009; Rowson, 1991). Apart from al-Kindī and al-'Āmirī, this inclusive mentality was also shown by Shaykh al-Ishrāq, Suhrawardī al-Maqtūl (d. 1191), who has taken as the sources of his philosophy not only philosophical doctrines of Muslim philosophers and mystics, but also Greek and Persian philosophers and sages (Aminrazavi, 2014; Ziai, 1990).

Apart from taking foreign sources, the inclusive attitude can also be detected quite easily in the way by which the proponents of Islamic culture are taken among the philosophers or mystics in choosing their teachers or disciples or in the case of rulers in appointing their officers (Kartanegara, 2007b). In particular, a great Persian Sufi and poet, Jaläl alDīn Rūmī (d. 1273) took as his disciples not just from among Muslims, but also Jews, Christians and even Zoroastrians (Kartanegara, 1986). They were treated equally well and were not forced to convert into Islam. The view of Islam is the mercy for the world 'rahmah lil-'âlamīn' (peace for the world). Therefore there is no mistake in taking or accepting nonMuslims as his disciples. When Mawlānā Rūmī passed away in year 1273, the funeral service was attended by Muslim disciples and non-Muslims alike. They read their own scriptures, the Qur'ān, Injīl dan Zabūr (Kartanegara, 1986, p.25). In particular, Christian disciples saw in Rūmī Jesus' doctrines of love were materialized, while Jewish disciples saw him as the embodiment of Moses' doctrines, and so on. This practical wisdom should be followed after by us, especially in big cities like Jakarta and Kuala Lumpur, where the attitude towards the others is very much exclusive (Kartanegara, 2005a).

The inclusive attitude in choosing teachers can be observed from the teachers Abū Nașr al-Fārābī (d. 950) chose from him. It is reported that al-Fārābī, known as the second teacher (al-Mu'allim Thânî) after Aristotle, the first teacher, when he came to Baghdad in the early part of the tenth century studied Aristotlian logic and philosophy with two Christian teachers Yohanna b. Haylān and Mattā Bishr b. Yūnus (Fakhry, 2004, p.108). It indicates that one of his disciples, who became famous in Baghdad, was a Jacobite Christian Yahyyā bin 'Adī. Ibn 'Adī himself was in turn one of the important teachers of Abū Sulaymān al-Sijistānī (d. 987), a very famous logician and philosopher in Baghdad after al-Fārābī left Baghdad in 942 for Aleppo (Leaman, 2013). From this perspective, the differences in religion between teachers and students did not slow down the process of learning between them (Huda, \& Kartanegara, 2015b). In particular, they did not choose or deny their teacher exclusively on religious ground. As long as the teachers are qualified in their fields, they would gladly choose them as their teachers (Huda, \& Kartanegara, 2015c). The last example of this inclusivism can be observed from political arena, that is, the recruitment of governmental officers by Muslim rulers. At that time, Hārūn alRashīd, a famous 'Abbāside caliph, appointed Bakhtishu II, a famous Zorostrian physician, as the royal doctor as well as the director of main hospital in Baghdad (Haque, 2004; Huff, 2003). A century later, Buyid ruler in Baghdad, 'Adud alDawlah appointed the Christian Nașr b. Hārūn his wazir (minister) and the Zoroastrian Abū Nașr Khawardasā the state treasurer (Aminrazavi, 2014; Kraemer, 1992; Watt, 2008; Ziai, 1990). 


\subsection{Humanism (Egalitarianism)}

In terms of the particular meaning of humanism, there should be viewed on an outlook that treats people on humanistic basis, where it should not be considered out of the basis such as race, cast, colour, position, or even religion (Said, 2004). As a result, Egalitarianism which views man to have the same position, degree and right, refers to the category of humanism. Apart from that, the history of Islamic culture was replete with so many examples for this kind of humanism. Our prophet Muhammad PBH once said, there are no excellences of the Arabs over non-Arabs. Abū Uthmān al-Hujwirī, in his Kashf al-Mahjūb, when comparing humanistic quality between prophet Muḥammad and prophet Ibrāhīm, relates that prophet Ibrāhīm will not eat unless someone accompanies him (Ramadan, 2006). In particular, prophet Ibrāhīm should wait for one or two hours for him. One day he waited more than six hours before finally someone passed by him. He called and invited him for dine. However, before they started to eat prophet Ibrāhīm asked about his job. When the man said that his job is to make idols, immediately he asked him to leave, thinking that he was the idol worshiper, therefore he committed shirk or associating God with the others (Ali, 2011). But at that very night, al-Hujwiri says, God gave him warning asking him why he wasn't pleased to share bread with someone whom He has served for 70 years (AlHujwīīi, 1970, p.317). Meanwhile, al-Hujwîî gives a different picture, when he told us about Prophet Muhammad's attitude towards the others. He informed us that when a Quraysh tribal chief came to see him, spontaneously our prophet took off his mantle and spread it on the ground for the chief to sit down although he knew that he wasn't a Muslim. Then he asked his companions to always give a respect to any tribal chief, regardless of his religion (al-Hujwirī, 1970). This is a clear example of humanistic mentality of our prophet Muhammad PBH., who views men not from his lineage, or even their religion, but purely humanity.

Another example related to this issue may be taken from Mawlānā Rūmī's defence for his Christian disciple, when he was discredited by his Muslim fellows saying that his knowledge about Islamic religion was not quite right (Kartanegara, 1986). In that case Mawlānā did not take side of Muslim disciples, simply because they were Muslim, but defended Christian disciple for the sake of truth. Joel Kraemer in his book, Philosophy in the Renaissance of Islam gives us another example to this effect. He states that Abū Sulaymān al-Sijistānī, had a philosophical circle (majīis falsafí) in Baghdad, whose members were not only Muslim scholars but also non-Muslim such as Christian, Jewish, Zoroastrian etc (Kraemer, 1986, Bakar, 1999). According to him, the principle that bound them together was 'universal friendship' or, as they called it, 'șadāqah' that transcends tribal, ethnic, colour and even religious bindings. This friendship was built upon the humanistic principle that sees men for their humanness, not for other reasons (Kraemer, 1986, p.48).

The last sample for this humanistic spirit can be extracted from an ethical work Kitāb al-Akhlāq wa al-Siyar by Ibn Hazm (d. 1165), an accomplished scholar from Andalusia. Ibn Hazm's egalitarianism was clearly seen when in one occasion he criticized someone who was too proud of his family. He said to him that one's nobility was not necessarily determined by his genealogy (Laylah, 1990; Marlow, 2002). Even a prophet cannot guarantee that his child will become a righteous man, simply because he was a prophet's child. It was possible that children of a prophet became unbeliever, such as the case of Prophet Noah's son, Kan'ān. On the other hand, it was quite possible too that an 'illicit' child became a very great and influential figure, such as the case of Abū Muslim al-Khurasānī (Laylah, 1990, p.79). It does not in any means that Ibn Hazm agreed with illicit relationship, nor did he disregard good genealogical background for a marriage, but simply as a warning that genealogy par se cannot guarantee one's nobility. Humans are basically the same. It is piety that will make them different, not others else.

\subsection{Tolerance}

Muslim ummah is known in the Past due to their tolerance (Friedmann, 2003; Ramadan, 2006). We can see this phenomenon in many different fields and places, as will be clear from the following examples. First of all, it occurred in the field of politics (Kamali, 2001). Muslim power in relatively short time conquered the surrounding countries like Egypt, Syria and Persia (Norton, 1993). When the Muslim conquered these areas, there had already existed and developed a number of learning centres. However, they did not bother or interfere with their academic activities, including philosophical and scientific studies that had been going on far before Islam came. A great number of learning centres in Syrian cities, such as Antioch, Harran, Edessa etc., still existed and developed far after the Muslim had conquered Syria and Iraq. The Arab conquest in general did not interfere with academic enquiries by scholars in Edessa, Nisibis and other learning centres in the Middle East (Fakhry, 2004). As a result, these centres of philosophical and theological studies by Christian scholars continued to run as it should be and they enjoyed the freedom of thought given to them by Muslim authorities.

In line with these centres, Muslim scholars did learn rational sciences, such as mathematics, astronomy, medicine, 
and other philosophical sciences (Leaman, 2013). Many of them studied under the guidance of Christian teachers as happened to al-Fārābī and Ibn Sīnā (Bakar, 1999). In addition, Muslim people, especially, the rulers, have taken nonIslamic educational systems and institutions as models. There are many scientific devices, such as observatories and also hospital, even according to another version, an academy like Bayt al-Hikmah, were built upon Yundishapur's models, the biggest center of learning in Persia (Fakhry, 2004, p.4). This center, according to one report, had continued to exist and to flourish until the ninth century, and diminished only after the foundation of Bayt al-Hikmah by caliph alMa'mūn, the son of Hārūn al-Rashīd (Netton, 2013). Moreover, non-Muslim minority communities, such as Christian, Jewish and Zoroastrian, could live and practice their religions relatively freely under the government of Muslim rulers. According to Prof. Joel Kraemer, non-Muslim minorities could co-exist well under Buyid authority. He tells us that on the west side of Baghdad in the tenth century there were 8 Christian monasteries, and 6 churches, and 3 monasteries and 5 churches on the east side (Kraemer, 1992, p.76). At this point of view, the Jewish community in Baghdad enjoyed the tolerance of Buyid rulers, while Benjamin of Tudelo, who visited Baghdad in the twelfth century, found in this city around 40.000 Jews, 28 synagogues, and 10 academies of learning (p.78).

The Sabeans in Harran were considered and declared as 'the protected people' (Fukuyama, 2001). Like Christians, their contribution to the medieval Islamic culture in the realm of philosophy, science, and literature was considerable. Like the Christians, they played key role in transmitting encyclopaedic culture of antiquity to the Islamic world, their main interests being in medicine, astronomy and mathematics (Kraemer, 1992, p.85). Along with the Jews, Christians, and Sabeans, the Mazdaeans (Zoroastrians) also enjoyed the legal status of a protected People. The attitude of the Buyids toward the Mazdaeans was indulgent, perhaps because of their special affinity for the ancient Iranian heritage. The Zoroastrian Abu Nasr (Nașir) Khwashada was appointed 'Aḍud al-Dawlah's treasurer in Baghdad and served in other capacities for the Buyids and 'Ali b. al-'Abbās al-Majūsī was his private physician and dedicated his great medical work, Kitab al-Mâliki (Liber regius) to him (Fakhry, 2004). Moreover, when Muslim population in Shiraz attacked the Mazdaeans, 'Adud al-Dawlah punished the offenders severely.

On the other hand, the conditions of minority communities who lived in big cities under Muslim hegemony were probably same. Karen Amstrong (2001) in her book Muhammad the Prophet shows us how Christian and Jewish people enjoyed their religious freedom and lived in peace and had freedom to practice their religions and everyday activities under the reign of Muslim Andalusian rulers, especially in Cordova. Only when certain non-Muslim communities, especially Christian-ridiculed Islam as religion publicly, they were given severe punishments by the authorities (Armstrong, 2001). Otherwise, the lives of these minority people under Muslim government ran in relatively free and peaceful sphere (Friedmann, 2003; Nasr, 2010; Soroush, 2000). Finally, tolerant attitude of Muslim community towards non-Muslim can be deduced from the fact that non-Muslim scholars were allowed to attend and participate in several scientific seminar organized by Muslim scholars or rulers. With this regard, Kraemer (1992) told us that the participants of Abū Sulaymān al-Sijistānī's philosophical circle were not just Muslims but also Christians, Jews, Zoroastrians and others. Even unbelievers, atheists, and materialists at certain circles were allowed not only to attend but also participate in scientific and religious discussions and seminars. As a result, the pious Andalusian theologian by the name of Abū 'Umar Ahmad Mahmund al-Sa'dī, visiting toward the end of the tenth century, was shocked by excessive tolerance of the Bagdadians. It indicates that at the first session he attended there were present not only Muslim of all sects, but also infidels, Mazdeans, materialists, atheists of every sort (Kraemer, 1992, p.59). At this point of view, we can take into consideration to these samples simply as an illustration on how this tolerance, as one of the ideals of civil societies, was really practiced by people of the Cosmopolitan Baghdad and thus could be taken as a peaceful reflection to the contemporary modern world (Bakar, 2015).

\subsection{Democracy (Freedom of Expression)}

In line with the reason, freedom, and democracy in the Islamic notion, one of essential attributes of democracy is individual freedom to express his opinion, and the freedom of thought (Soroush, 2000). In this view, there should be any particular control in what act should be taken. The point which needs to be considered in particular on how this freedom of thought was carried out and practiced by Muslim ummah (community) who lived in big cities in their golden ages should be well amended clearly with regard to the benefit of humankind. The freedom to express one's opinion or even to level his criticism at the ruling class can be observed quite clearly in Abū Hayyān al-Tawhīdī's Akhlāq al-Wazírayn (The Characters of Two Prime Ministers), where al-Tawhīdī criticized the characters or conducts of two Buyid ministers, Ibn 'Amīd and Ibn Ibn 'Abbād (al-Tawḥīīi, 1997). According to him, Ibn 'Amīd was too stingy in waging his subordinates or employees, even the very important one like Miskawayh, an accomplished philosophers and historian. Moreover, Miskawayh was paid by Ibn 'Amīd the minimum salary (Rowson, 1988). It indicates that there is a great example to be a 
good pattern for moral character of a wazir like him.

In addition, the freedom to express opinion can also be seen in the literature works. Al-Jāhiz, for example, in his book, al-Bukhalā' (The Stingy People) criticizes a number of public figures, who were very influential in society, but suffered from moral flaws. These figures were considered by al-Jāhiz too stingy for their position, which is interestingly enough that in fact he includes al-Kindī, a famous and first Muslim philosopher, among the bukhalā' (Al-Jāhiz, 1989). In particular, the freedom of thought again can be demonstrated in the fields of philosophy and theology (Watt, 2008). Here, a philosopher or theologian can freely express his opinion, even a controversial one that ran against public opinion. Abu Bakr al-Rāzī, a very well-known physician, for example, wrote a highly controversial theory on the five eternal entities, in his famous work al-Qudamā' al-Khamsah (Al-Rāzī, 1973, p.194-216). 'The Faylasuf Rāzỉ is also taken to begin with objecting to reliance on revelation (Hodgson, 2009), since more than one doctrine (religion) is supported by revelation and there is no way to decide between the conflicting claims. With this regard, such appeals can only lead to destructive conflict among mankind, which cannot be God's purpose. Then, all humans alike being endowed with reason has the hopeful essences based on God's intention for reaching the truth.

Naturally, his statement would agitate and bring about many objections. But those who did not agree also had any rights to voice their opinions against it (Kamali, 1997). Abū Hātim al-Rāzī, an Ismī'ilī dā'ī (preacher) was shocked like any other adherent of a monotheistic revelation (Rowson, 1991). He regarded the philosopher's statement as the dangerous and arrogant rejection of historical revelation recognized by the community, in favour of the momentary speculation of an individual. As a result, he wrote his criticism against Abū Bakr al-Rāzī', saying that we all have reason, but we do not have it all alike (Leaman, 2013). Hence there must be an ultimately authoritative leader if truth is to be found at all, as surely God desires it to be; this leader must be a prophet bringing revelation. In fact the proponents of individual reason are different among themselves just as did the proponents of revelation. In this view, Rāzi had condemned important conclusions of great teachers and asked if he, their disciple, thought himself wiser than they who had thought him. It could be implied that the wisest philosophers make mistakes and have no way of coming to a final settlement (Fakhry, 2004; Hodgson, 2009).

In line with something important to note here, the criticism was conveyed not through violence, as very often take place nowadays in the Islamic world, but through scientific mechanism, not physically and emotionally but rationally and logically. For example, the criticism to al-Rāzì's statement was levelled by al-Bīrūnī (d. 1031) in one of his writings (Hodgson, 2009). It is true that Abū Bakr al-Rāzĩ died old and naturally well indicates the degree of freedom where the people of city Rayy had for such a controversial man and issue. The sample for freedom of expression can also be seen from a theological discourse, especially between Sunnite and Mu'tazilite theologians (Soroush, 2000). When in general most people defended the eternity of the Qur'an, some Mu'tazilite theologians argued that it was not eternal, but created. In particular, when the majority of people believed that the Qur'an inimitable, both in term of content and style, alNaz̧zām, a Mu'tazilite theologian, stated that the Qur'an could be imitated by men, even some of them, like al-Mutanabbī, had composed more beautiful poem than the Qur'an (Kraemer, 1992, p.48). Only in the term of content, he acknowledged, that the Qur'an cannot be imitated. It is important to note that tolerance should be taken into consideration in the midst of the differences in terms of opinion or views. As the expression through such ideas in rather impressive manners, much of these works were very well preserved until now in the Islamic cultural heritage. Consequently, the freedom of expression was exercised to find a tele-discussion between the two towering figures of the eleventh century, al-Bīrūnī, a real polymath, and Ibn Sīnā (d. 1037) the most famous Muslim Peripatetic philosopher. As a result, considering a precious lesson can draw a picture from these great figures and agents of the Islamic culture.

\section{Conclusion and Recommendation}

Through critically exploring and dealing with the certain ideals of civil society based on the Islamic world, this study does elucidate profound discussions at a conceptual level, which can be transformed into technical requirements and specifications, illustrating the proponents of Islamic culture comprising men of letters, philosophers, mystics, scientists or theologians practiced the ideals of their civil societies. This study refers to the proponents of Islamic culture theoretically and practically, mainly in the period of the glory of Islamic culture between the tenth and thirteenth centuries. This study reveals that there is some core significant enlightenment for the formal structure of civil society. In particular, this study demonstrates that although the term of 'civil society' might have not yet been invented in the classical Islam and rather used in adab (civilised) and peradaban (civilisation), in practical level the core values criteria of civil society were already discussed, exercised and practiced by the proponents of Islamic culture long before the Western scholars invented the term 'civil society.' In this paper, core discussion on civil society has been investigated by putting forward the concrete forms of statements or actions and the proponents of Islamic culture. Investigating the concept of civil society in the 
perspective of lexicographical sources explores the historical and cultural approach into what kind of significant reflection should be taken into consideration for theoretical and practical aspect in our society. As a result, this is expected to contribute a better awareness and a more informed citizenry.

\section{References}

Al-Ghazālī, A.H. (n.d.) IhyãđUlüm al-Dīn [Revival of the religious sciences] vol. 2, ed. Dr. Badawi Thabana. Semarang: Toha Putra.

Al-Hujwirīi, A.U. (1970) Kashf al-Mahjūb, trans. Reynold Nicholson, New Delhi: Kitāb Bhavan

Ali, M. M. (2011). The religion of Islam. Ahmadiyya Anjuman Ishaat Islam Lahore USA.

Al-Jāhiż. (1989). al-Bukhalā'. Jeddah: Dār al-Maṭba'at al-Ḥāditḥah.

Al-Rāzī, A.B. (1973) al-Qawl fĩ al-Qudamā' al-Khamsah, in Rasāill Falsafiyyah, Beirut: Dār al-Afaq al-Jadīdah. (194-216).

Al-Tawhīdī, A.H. (1997). Akhlāq al-Wazīrayn: al-Șihāb b. 'Abbād wa Ibn al-'Amīd. Beirut: Dār al-Kutub al-'Ilmiyyah.

Aminrazavi, M. A. R. (2014). Suhrawardi and the School of Illumination. London \& New York: Routledge.

Aminrazavi, M. A. R., \& Nasr, S. H. (2013). The Islamic intellectual tradition in Persia. London \& new York: Routledge.

Armstrong, K., \& Syah, S. (2001). Muhammad sang nabi: sebuah biografi kritis. A. Maghastria (Ed.). Surabaya: Risalah Gusti.

Ayubi, N. (2003). Political Islam: religion and politics in the Arab world. New York: Routledge.

Bakar, O. (2015). Islamic Civilisation and The Modern World: Thematic Essays. Bandar Seri Begawan: UBD Press.

Bakar, O. (2010). Islam and the Three Waves of Globalisation: The Southeast Asian Experience. Islam and Civilisational Renewal (ICR), $1(4)$.

Bakar, O. (1999). The history and philosophy of Islamic science. Camrbridge, UK: Islamic Text Society

Bakti, A. F. (2005). Islam and modernity: Nurcholish Madjid's interpretation of civil society, pluralism, secularization, and democracy. Asian Journal of Social Science, 33(3), 486-505.

Brown, L. C. (2013). Religion and state: The Muslim approach to politics. Columbia University Press.

Castells, M. (2008). The new public sphere: Global civil society, communication networks, and global governance. The aNNalS of the american academy of Political and Social Science, 616(1), 78-93.

Edwards, M. (2009). Civil society. Cambridge, UK: Polity.

Eickelman, D. F., Piscatori, J., \& Piscatori, J. P. (2004). Muslim politics. Princeton University Press.

Fakhry, M. (2004). A history of Islamic philosophy. London \& New York: Columbia University Press.

Friedmann, Y. (2003). Tolerance and coercion in Islam: interfaith relations in the Muslim tradition. London \& New York: Cambridge University Press

Fukuyama, F. (2001). Social capital, civil society and development. Third world quarterly, 22(1), 7-20.

Hanafi, H. (2002). Alternative conceptions of civil society: A reflective Islamic approach. Alternative conceptions of civil society, 171-189.

Hann, C. M., \& Dunn, E. (1996). Civil society: Challenging western models. Psychology Press

Haque, A. (2004). Psychology from Islamic perspective: Contributions of early Muslim scholars and challenges to contemporary Muslim psychologists. Journal of Religion and Health, 43(4), 357-377.

Hindu, A.A.I. (1900). al-Kalim al-Rūhāniyah fi al-Hikam al-Yūnāniyyah. Qāhirah: Mathba' al-Taraqqī.

Hodgson, M. (1977). The Venture of Islam, vol. 1, Chicago and London: The University of Chicago Press.

Hodgson, M. G. (2012). The Venture of Islam: Iman dan Sejarah dalam Peradaban Dunia. Paramadina.

Huda, M., \& Kartanegara, M. (2015a). Islamic Spiritual Character Values of al-Zarnüji's Ta'lim al-Muta'allim. Mediterranean Journal of Social Sciences, 6(4), 229.

Huda, M., \& Kartanegara, M. (2015b). Ethical Foundation of Character Education in Indonesia: Reflections on Integration between Ahmad Dahlan and al-Zarnuji. Persidangan Antarabangsa Tokoh Ulama Melayu Nusantara (PanTUMN), (DOI: 10.13140/RG. 2.1.5082.1605), 404-420.

Huda, M., \& Kartanegara, M. (2015c). Aim Formulation of Education: An Analysis of The Book Ta'Im al- Muta'allim. International Journal of Humanities and Social Science, 5(2), 143-149.

Huxley, A. (2014). The perennial philosophy. New Canadian Library.

Hodgson, M. G. (2009). The Venture of Islam, Volume 1: The Classical Age of Islam. University of Chicago Press.

Hooghe, M., \& Stolle, D. (2003). Generating social capital: Civil society and institutions in comparative perspective. Palgrave Macmillan. Huff, T. E. (2003). The rise of early modern science: Islam, China and the West. London \& New York: Cambridge University Press.

Inglehart, R., \& Welzel, C. (2005). Modernization, cultural change, and democracy: The human development sequence. Cambridge University Press.

Kaldor, M., Anheier, H., \& Glasius, M. (2003). Global civil society. Cambridge: Polity.

Kaldor, M. (2003). The idea of global civil society. International Affairs (Royal Institute of International Affairs 1944-), 583-593.

Kamali, M. (2001). Civil society and Islam: a sociological perspective. European Journal of Sociology, 42(03), 457-482.

Kamali, M. (2006). Multiple modernities, civil society and Islam: the case of Iran and Turkey. Liverpool: Liverpool University Press.

Kamali, M. (2010). Racial discrimination: institutional patterns and politics. New York: Routledge.

Kamali, M. H. (1997). Freedom of expression in Islam (p. 186). Cambridge: Islamic Texts Society.

Kartanegara, R. M. (1986). Renungan mistik Jalal ad-Din Rumi. Jakarta, Pustaka Jaya.

Kartanegara, M. (2000a). Membangun Kerangka IImu: Perspektif Filosofis.Problem dan Prospek IAIN: Antologi Pendidikan Tinggi Islam, Jakarta: Ditbinperta Islam. 
Kartanegara, R. M. (2000b). Mozaik khazanah Islam: bunga rampai dari Chicago. Paramadina.

Kartanegara, R. M. (2002). Menembus batas waktu: panorama filsafat Islam. Mizan.

Kartanegara, R. M. (2003a). Menyibak tirai kejahilan: pengantar epistemologi Islam. Bandung: Mizan.

Kartanegara, M. (2003b). Integrasi IImu dalam Perspektif Filsafat Islam.

Kartanegara, M. (2005a). Islam dan Multikulturalisme: Sebuah Cermin Sejarah.dalam Baidhawy, Zakiyuddin (ed.), Reinvensi Islam Multikultural, Surakarta: PSB UMS.

Kartanegara, M. (2005b). Integrasi ilmu: sebuah rekonstruksi holistik. Arasy

Kartanegara, M. (2005c). Integrasi IImu. Bandung: Mizan.

Kartanegara, M., \& Abilawa, M. S. (2006a). Reaktualisasi tradisi ilmiah Islam. Baitul Ihsan.

Kartanegara, M., \& Hizbullah, W. (2006b). Gerbang kearifan: sebuah pengantar filsafat Islam. Lentera Hati.

Kartanegara, M. (2007a). Mengislamkan Nalar: Sebuah Respon terhadap Modernitas. Erlangga.

Kartanegara, M., \& Alkaf, H. (2007b). Nalar Religius: Memahami Hakikat Tuhan, Alam, dan Manusia. Erlangga.

Kartanegara, M. (2009). Filsafat Islam, Etika dan Tasawuf, Jakarta: Ushul Press.

Kartanegara, M. (2015). Essentials of Islamic Epistemology: A Philosophical Inquiry into the Foundation of Knowledge, Bandar Seri Begawan: UBDPress.

Keane, J. (2003). Global civil society? (p. 5). Cambridge: Cambridge University Press.

Kraemer, J. L. (1986). Philosophy in the renaissance of Islam: Abū Sulaymān Al-Sijistānī and his circle (Vol. 8). Brill Archive.

Kraemer, J. L. (1992). Humanism in the Renaissance of Islam: the cultural revival during the Buyid Age (Vol. 7). Brill.

Laylah, M. A. (1990). In Pursuit of Virtue the Moral Theology and Psychology of Ibn Hazm Al-Andalusi [384-456 Ah 994-1064 Ad], with a Translation of His Book Al-Akhlaq Wa'l-Siyar. London: Țāhā Publishers Ltd.

Leaman, O. (2013). History of Islamic philosophy. London \& New York: Routledge.

Lipschutz, R. D. (1992). Reconstructing world politics: the emergence of global civil society. Millennium-Journal of International Studies, 21(3), 389-420

Marlow, L. (2002). Hierarchy and egalitarianism in Islamic thought. London \& New York: Cambridge University Press.

Miskawayh. (1952). al-Hikmah al-Khālidah, ed. 'Abd al-Raḥmān Badawī (Kairo: Maktab al-Nahḍah al-Mișriyyah.

Nasr, S.H. (1976). Islamic Science: an Illustrated Study. London: World of Islam Festival Publishing.

Nasr, S. H. (2010). Islam in the modern world: Challenged by the west, threatened by fundamentalism, keeping faith with tradition. New York: Harper One.

Newton, K. (2001). Trust, social capital, civil society, and democracy. International Political Science Review, 22(2), 201-214.

Netton, I. R. (2013). Encyclopaedia of Islam. New York: Routledge.

Norton, A. R. (1993). The future of civil society in the Middle East. The Middle East Journal, 205-216.

Ramadan, T. (2006). In the Footsteps of the Prophet: Lessons from the Life of Muhammad. Oxford University Press.

Rowson, E. K. (1988). A Muslim Philosopher on the Soul and its Fate. Phillip Merlan,'Monopsychism, Mysticism, Metaconsciousness: Problem of the Soul in the Neoaristotelian and Neoplatonic Tradition', International Archives of the History of Ideas, 2.

Rowson, E. K. (1991). A Muslim Philosopher on the Soul and its Fate. Àl-'Āmirî's „Kitāb al-Amad'alā l-abad”.

Ryding, K. C. (2005). A reference grammar of modern standard Arabic. Cambridge university press.

Said, E. W. (2004). Humanism and democratic criticism. Columbia University Press.

Scholte, J. A. (2002). Civil society and democracy in global governance. Global Governance, 281-304.

Soroush, A. (2000). Reason, freedom, and democracy in Islam: Essential writings of Abdolkarim Soroush. Oxford University Press.

Tibi, B. (2001). Islam between culture and politics. Macmillan.

Turam, B. (2004). The politics of engagement between Islam and the secular state: ambivalences of 'civil society'1. The British journal of sociology, 55(2), 259-281.

Watt, W. M. (2008). Islamic philosophy and theology. London \& new York: Transaction Publishers.

Wehr, H., \& Cowan, J. M. (1979). A dictionary of modern written Arabic:(Arab.-Engl.). Otto Harrassowitz Verlag.

Yilmaz, I. (2005). State, law, civil society and Islam in contemporary Turkey. The Muslim World, 95(3), 385-411.

Ziai, H. (1990). Knowledge and Illumination a Study of Suhrawardi's Hikmat Al-Ishraq. 